\title{
TITLE:
}

\section{$<$ Note> On the Chimpanzees of Kakungu, Karobwa and Ntakata}

$\operatorname{AUTHOR}(\mathrm{S}):$

Zamma, Koichiro; Inoue, Eiji; Mwami, Mtunda; Haluna, Bunde; Athuman, Silindila; Huseni, Shaka

\section{CITATION:}

Zamma, Koichiro ...[et al]. < Note> On the Chimpanzees of Kakungu, Karobwa and Ntakata. Pan Africa News 2004, 11(1): 8-10

ISSUE DATE:

2004-06

URL:

http://hdl.handle.net/2433/143436

RIGHT:

Copyright (C) Pan Africa News. 


\section{<NOTE>}

On the Chimpanzees of Kakungu, Karobwa and Ntakata

\section{Koichiro Zamma, Eiji Inoue, Mtunda Mwami, Bunde Haluna, Silindila Athumani \& Shaka Huseni Kansyana Research Camp Mahale Mountains National Park}

The distribution of chimpanzees on the eastern shore of Lake Tanganyika was investigated by Kano (1) from 1965 to 1967. Since then, there has been little information from this area except for the Kasoje forest, where chimpanzees have been studied for a long time.

We visited Kakungu, Karobwa and Ntakata to the north of the Mahale Mountains and made a brief survey of chimpanzees in October 2003. In the past, Kano observed beds of chimpanzees at Kakungu and saw chimpanzees at Karobwa. We heard the vocalization of chimpanzees at Kakungu and observed a chimpanzee at Karobwa. We also observed beds and feces of chimpanzees at Kakungu and Karobwa; however, we could not obtain evidence of chimpanzees at Ntakata.

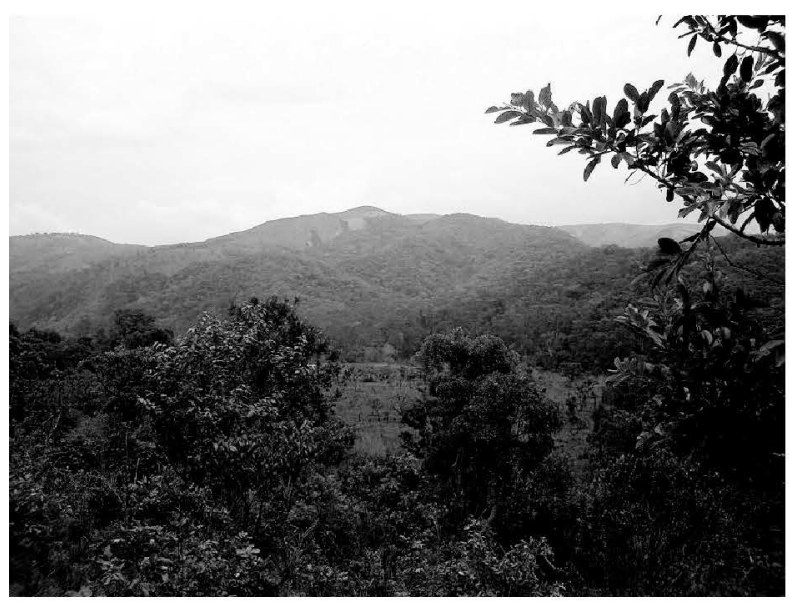

Figure 1. The overview of Ntaka forest

\section{Methods}

We traveled on foot between October 12 and 17, 2003; from Lukoma to Kakungu on the first day, around Mt.Kakungu on the second day, from 
Kakungu to Lubalisi via Mt.Karobwa on the third day, from Lubalisi to Ikuburu on the forth day, from Ikuburu to Ntakata on the fifth day, and from Ikuburu to Lukoma on the sixth day (Figure 1). The altitude of this area is from $770 \mathrm{~m}$ (Lukoma) to $1,880 \mathrm{~m}$ (Mt. Karobwa). This area is mainly covered with woodlands, bamboo bushes, and riverine forests. Most of the grasses under the woodlands and the bamboo bushes were burned. Farmland is spread near villages. We saw more green leaves in the riverine forest than in the other types of vegetation because we surveyed in the early rainy season.

We recorded encounters, vocalization, beds, feces, and food remnants of chimpanzees. We also recorded encounters and vocalizations of other mammals. Five samples of hair remained on the beds, and five feces and two samples of saliva were collected for the DNA analysis.

\section{RESULTS}

\section{From Lukoma to Kakungu Village (9:49-13:56, Oct. 12)}

No vocalization of chimpanzees. We saw a bush duiker (Sylvicapra grimmia) at 11:07.

\section{At Kakungu Village I (13:56-16:01, Oct. 12)}

We saw two beds of chimpanzees from the village. These were in a Sterculia quinqueloba tree in the woodland on the west side of Mt. Kakungu. It took us 14 minutes to go there from the village. One of the beds was reached by climbing to it and the hairs of chimpanzees were collected.

\section{At Kakungu Village II}

\section{(17:38-20:27, Oct. 12 and 6:15-7:53, Oct. 13)}

We heard the vocalization of chimpanzees from the riverine forest on the south side of $\mathrm{Mt}$. Kakungu between 18:29 and 18:53, Oct. 12 and at $6: 46$, Oct. 13. We heard the vocalizations of more than six chimpanzees.

\section{In the forest of Mt. Kakungu (7:53-16:27, Oct. 13)}

We tracked around the riverine forest on the south side of Mt. Kakungu. The actual time of walking was about three hours. There were some plants that were confirmed as foods of the chimpanzees at Mahale. Pseudospondias microcarpa, Ficus vallis-choudae, Ficus congensis and Landolphia owariensis were bearing fruits. Garcinia huillensis, however, which was fruited in the Kasoje Forest, did not bear fruits at that time.

We observed eighteen beds. We climbed up to four of them and collected hair samples. We also collected two feces and a wadge of Ficus vallis-choudae. The seeds of Canthin sp. and Pseudospondias were included in these feces. We saw a red-tailed monkey (Cercopithecus ascanius).

\section{At Kakungu Village III}

(16:27-21:00, Oct. 13 and 6:15-7:45, Oct. 14)

We could not hear the vocalization of chimpanzees.

\section{From Kakungu Village to Lubalisi via Mt. Karobwa (7:45-18:44, Oct. 14)}

We heard vocalization three times near Mt. Karobwa. At first, when we were passing Mabungu Village, we heard vocalization from the southeast side of Mt. Silafu (10:50-10:55). The second vocalization of about 10 chimpanzees came from the same place at 13:05 when we climbed halfway up Mt. Karobwa.

After we passed Mt. Karobwa, we heard the vocalization of more than two chimpanzees from the southeast side of Mt. Karobwa (16:12-16:19). When we approached the direction of the vocalization, we witnessed a chimpanzee running into bushes (16:22). We also collected three feces. This site was about $5 \mathrm{~km}$ away from Mt. Silafu. On the summit of Mt. Karobwa, a bed was observed.

\section{At Lubalisi}

(18:44-19:05, Oct. 14 and 6:10-7:19, Oct. 15)

No vocalization of chimpanzees was heard.

From Lubalisi to Ikuburu (7:19-12:32, Oct. 15)

No vocalization of chimpanzees was heard.

\section{At Ikuburu I}

(12:32-21:30, Oct. 15 and 6:38-7:45, Oct. 16)

No vocalization of chimpanzees was heard. 


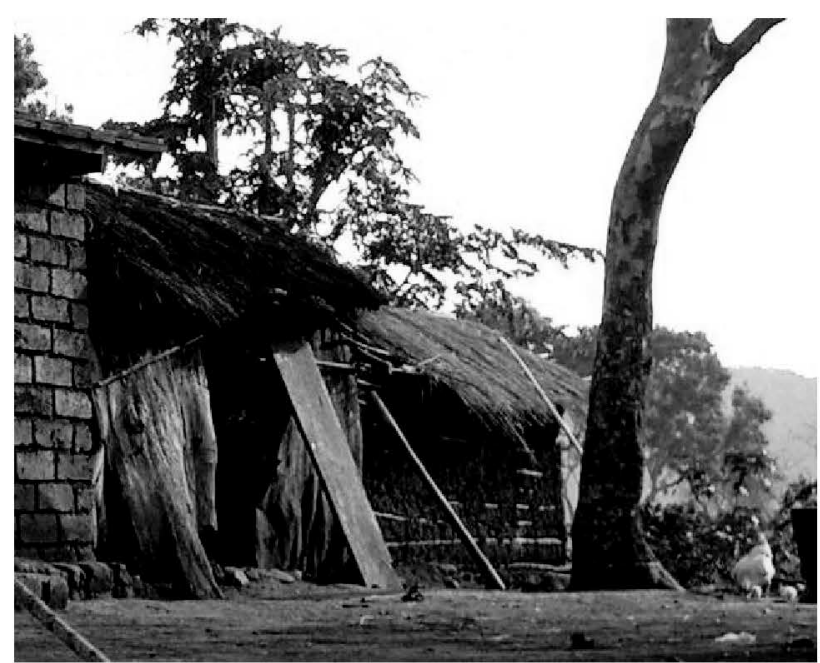

Figure 2. Kakungu Village

\section{Between Ikuburu and the Ntakata Forest (7:45-19:16, Oct. 16)}

We spent an hour and a half in the Ntakata Forest. No vocalization of chimpanzees was heard. We observed remnants of foods, the fruits of Ximenia africana, but could not determine whether they were eaten by chimpanzees or not.

On the way to Ntakata, we heard the vocalization of a baboon (Papio cynocephalus) and observed a bush pig (Potamochoerus larvatus).

There are some riverine forests between Ikuburu and Ntakata. At Kamafiga Riv., Lwegele Riv., and Mlofesi Riv., we observed some plants that were known as foods of the chimpanzees at Mahale (Saba comorensis, Psychotria peduncularis, Ficus urceolaris, and Aframomum sp).

\section{At Ikuburu II}

(19:16-21:00, Oct. 16 and 7:01-8:42, Oct. 17)

No vocalization of chimpanzees was heard.

\section{From Ikuburu to Lukoma (8:42-12:48, Oct. 17)}

We could not hear the vocalization of chimpanzees. We observed a bushback (Tragelaphus scriptus) at 11:07.

\section{Discussion}

Our survey of the three forests

was brief, but we would like to discuss the number of groups and the possibilities of studying chimpanzees there.

At Kakungu, we heard the vocalization of chimpanzees and found beds. This shows there is at least one chimpanzee group. At Karobwa, we heard vocalization from two sites that are $5 \mathrm{~km}$ apart. This shows that there are at least two groups. At
Ntakata, we did not find any trace of chimpanzees during our trip; however, Moore heard vocalization in 2001, and Ogawa saw chimpanzees in 2003 (Moore and Ogawa, personal communication).

If further research is to be conducted, we believe that Kakungu would be the best choice as a site. The Kakungu forests where we heard vocalization and found beds are near Kakungu Village. Therefore, it is not so difficult to observe chimpanzees or traces of chimpanzees. It would be relatively difficult to study chimpanzees around the top of Mt. Karobwa due to the lack of water there. Mt. Silafu is not so far from Mabungu Village, and the place we heard vocalization at Karobwa is not so far from Lubalisi Village. Therefore, it may not be so difficult to conduct research at these sites. However, the environments of chimpanzees are getting worse because of poaching, prospecting for mineral resources, and commercial logging (Moore, personal communication). Ntakata is far from any village, so we would need to establish a camp if we conducted research there. If longer-term research is intended, a car would be necessary to bring food and tents there.

\section{Acknowledgements}

We thank Huseni Bakari, Shabani Faru and Jumanne Pesambili for helping us to stay in the villages. We also thank Hassani Mohamedhi, Crispin Mwinuka and Toshisada Nishida for their advice, Jim Moore and Hideshi Ogawa for comments, and Takahisa Matsusaka for logistic support. The field study was financially supported by a MEXT Grant-in-Aid for Scientific Research (Basic Research A1, \#12375003 to T. Nishida).

\section{Reference}

(1) Kano T 1972. Distribution and adaptation of the chimpanzee on the eastern shore of Lake Tanganyika. Kyoto University African Studies 7 : 37-129 